\title{
Clonal Dissemination of Genetically Diverse Fluoroquinolone-Resistant Extended-Spectrum Beta-Lactamase (ESBL)-Producing Escherichia coli ST131 in a Veterans Hospital in Southern Taiwan
}

\author{
Wen-Chung Chang ${ }^{*}$, Chung-Jung Wu ${ }^{2 *}$, Chuan-Shee Liu ${ }^{3}$, Yilin Tsai ${ }^{4}$, Jen-Jain Lee ${ }^{3}$, \\ Yuting Hsiao3, Shu-Ling Chou ${ }^{3}$, Chih-Hao Sun ${ }^{3}$, Chishih Chu4\# \\ ${ }^{1}$ Dentistry Division, Chiayi Branch, Taichung Veterans General Hospital, Taiwan \\ ${ }^{2}$ Internal Medicine Department, Chiayi Branch, Taichung Veterans General Hospital, Taiwan \\ ${ }^{3}$ Medical Laboratory Division, Chiayi Branch, Taichung Veterans General Hospital, Taiwan \\ ${ }^{4}$ Department of Microbiology, Immunology, and Biopharmaceutics, National Chiayi University, Taiwan \\ Email: "\#cschu@mail.ncyu.edu.tw
}

Received 3 May 2016; accepted 30 July 2016; published 2 August 2016

Copyright (C) 2016 by authors and Scientific Research Publishing Inc.

This work is licensed under the Creative Commons Attribution International License (CC BY).

http://creativecommons.org/licenses/by/4.0/

cc) (i) Open Access

\begin{abstract}
Uropathogenic Escherichia coli is the common pathogen to cause urinary tract infections (UTIs) and have become multidrug-resistant (MDR) extended-spectrum $\beta$-lactamase (ESBL) producers. The differences in the antimicrobial susceptibility, 5 bla genes, 12 virulence genes of 87 clinical ESBL-producing $E$. coli isolates and genomic variations and sequence types of 18 recurrent and repeated isolates from 9 patients were investigated. The 87 MDR-ESBL isolates collected mainly from indwelling urinary catheters (IUCs) and UTIs were highly resistant to fluoroquinolones, with over $50 \%$ of the isolates being resistant to cefepime and piperacillin/tazobactam and a few being resistant to carbapenem. These isolates carried at least two of the five bla genes examined, with

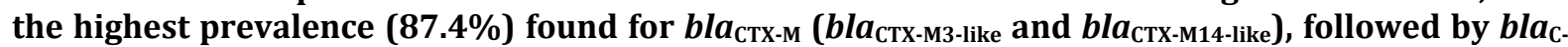
MY-2 $(80.5 \%)$ and $b a_{\mathrm{SHV}}(56.3 \%)$. The predominant virulence genes were the fimbriae gene fimH and the toxin genes cnf1 and hlyA in blood isolates and the capsule gene kpsMTII in UTI and blood isolates. Over $80 \%$ of the isolates carried yersiniabactin and aerobactin of siderophores. In 18

${ }^{*}$ Contributed equally

How to cite this paper: Chang, W.-C., et al. (2016) Clonal Dissemination of Genetically Diverse Fluoroquinolone-Resistant Extended-Spectrum Beta-Lactamase (ESBL)-Producing Escherichia coli ST131 in a Veterans Hospital in Southern Taiwan. Advances in Microbiology, 6, 590-601. http://dx.doi.org/10.4236/aim.2016.69059
\end{abstract}


isolates, the fluoroquinolone-resistant ST131 isolate of pulsotypes I and II with bla $_{\mathrm{CTX}-\mathrm{M}-15 \text { was }}$ clonally disseminated in the hospital. The genomic plasticity of these ST131 occurred mainly through the conjugative plasmids with differences in replicon types A/C, I1, FIA, FIB and Y, size and number. In conclusion, MDR ESBL-producing $E$. coli isolates differed in virulence genes of UPEC and antibiotic resistance associated with the sources. Plasmid acquisition and chromosomal variations increase the spread of fluoroquinolone-resistant UPEC ST131 worldwide.

\section{Keywords}

E. coli, ESBL, Virulence Genes, Antimicrobial Resistance, MLST

\section{Introduction}

Genetically diverse Escherichia coli is an opportunistic pathogen that causes gastroenteritis, bacteremia, bladder infections, meningitis or pus [1]-[3]. In urinary tract infections (UTIs), E. coli can infect from outside the body, resulting in direct urethra inflammation, and transport through the circulation system from a wound, or movement from nearby tissues. As the main pathogen to cause UTI, uropathogenic E. coli (UPEC) consists of different pathogenicity islands [4], which encode several virulence factors, including adhesins (such as type 1 fimbriae and $\mathrm{P}$ fimbriae), iron-associated siderophores (aerobactin genes iutA and iucDCBA, salmochelin genes iroBCDEN, and yersiniabactin genes fyuA-irp operon), toxins (i.e., hemolysin gene hlyA, cytotoxin necrotizing factor gene $c n f 1$, and secreted autotransporter toxin gene sat), the capsule (such as capsule K1/K5), and other factors (i.e., serum resistance gene traT and uropathogenic protein gene usp) [2] [5] [6].

Genetically related strains with multidrug resistance are the characteristics of UTI- and catheter-associated UTIs (CAUTIs)-associated E. coli, which carry similar virulence genes as UPEC [7] and account for more than $40 \%$ of all nosocomial infections in hospitals and nursing homes [3] [7]-[9]. Important factors that lead to ESBL-producing E. coli-associated nosocomial infection are the use of extended-spectrum cephalosporins and urethral catheterization [10]-[12]. The most prevalent uropathogenic E. coli ST131 strains differ in their uropathogenic virulence factors, are associated with phylogroup B2, and carry IncF, IncN, IncA/C, and IncI1 plasmids, with a size ranging from 50 to $>200 \mathrm{~kb}$ [13]-[16]. The aims of this study were to characterize the ESBL-producing $E$. coli with differences in uropathogenic virulence genes and to investigate the genomic and plasmid variations of $E$. coli ST131 based on nine episodes of recurrent infections and repeated isolation.

\section{Materials and Methods}

\subsection{Bacterial Sources}

A total of 101 clinical E. coli isolates were collected consecutively from IUCs, UTIs, blood, sputum, wounds and ears of patients from August 2010 to February 2011 and were identified as ESBL producers in the Medical Laboratory Division of Chiayi Branch, Taichung Veterans General Hospital. After the further identification of E. coli by biochemical methods, confirmation of ESBL at National Chiayi University and the removal of genetically identical isolates from same patient, 87 ESBL-producing isolates were analyzed. All of the E. coli isolates were routinely incubated on EMB agar for further use. Furthermore, 18 isolates from 9 patients who were infected recurrently or at different sites within a short period were investigated. A recurrent $E$. coli infection was defined as a patient who was infected by a culture-proven E. coli more than 1 month after the completion of the initial antimicrobial therapy.

\subsection{Antimicrobial Susceptibility Test}

Antimicrobial susceptibility to ampicillin (AMP, $30 \mu \mathrm{g}$ ), cefotaxime (CTX, $30 \mu \mathrm{g}$ ), ceftazidime (CAZ, $30 \mu \mathrm{g}$ ), ceftriaxone (CRO, $30 \mu \mathrm{g}$ ), cefotaxine/clavulanic acid (CTX/CLA, 30/10 $\mu \mathrm{g}$ ), ceftazidime/clavulanic acid (CAZ/CLA, 30/10 $\mu \mathrm{g}$ ), ciprofloxacin (CIP, $5 \mu \mathrm{g}$ ), nalidixic acid (NAL, $30 \mu \mathrm{g}$ ), levofloxacin (LVX, $5 \mu \mathrm{g}$ ), moxifloxacin (MXF, $5 \mu \mathrm{g}$ ), piperacillin (PIP, $100 \mu \mathrm{g}$ ), piperacillin/tazobactam (TZP, 100/10 $\mu \mathrm{g}$ ), cefepime (FEP, 30 $\mu \mathrm{g}$ ), ertapenem (ETP, $10 \mu \mathrm{g}$ ), imipenem (IPM, $10 \mu \mathrm{g}$ ) and meropenem (MEM, $30 \mu \mathrm{g}$ ) was determined using the 
disc-diffusion method and CLSI standards [17]. The antimicrobial discs were purchased from BD (Becton Dickinson and Company, Sparks, MD, USA). Escherichia coli ATCC 25922 was used as the reference strain. ESBL isolates were determined by the diameter differences of the inhibition zones between cefotaxine and cefotaxine/clavulanic acid or between ceftazidime and ceftazidime/clavulanic acid. AmpC production was also examined.

\subsection{PCR Detection of Genes for Antimicrobial Resistance and Virulence Factors}

The primers used to amplify genes for five $\beta$-lactamases and 12 virulence factors are listed in Table 1 . Three multiplex PCR sets were developed by modifying previous primer sequences. Antimicrobial resistance genes were detected by Multiplex PCR I for $b l a_{\mathrm{SHV}}, b l a_{\mathrm{CTX}-\mathrm{M} 3-\mathrm{like}}, b l a_{\mathrm{CTX}-\mathrm{M} 14-\mathrm{like}}, b l a_{\mathrm{TEM}}$ and $b l a_{\mathrm{DHA}}$ and by single PCR for bla $a_{\mathrm{CMY}-2}$. Twelve virulence genes were amplified by two multiplex PCR sets: hlyA, usp, sat, fyuA, ironN, iutA and iucD for multiplex PCR II and fimH, cnf1, traT, kpsMTII and papGII for Multiplex PCR III. All PCR products were separated by electrophoresis on a $2 \%$ agarose gel at $50 \mathrm{~V}$ for $120 \mathrm{~min}$. After ethidium bromide staining and UV illumination, the gel image was recorded and analyzed.

\subsection{Genomic, Plasmid, Multilocus Sequence Typing (MLST), and Sequence Analysis of Recurrent Isolates}

The procedure for PFGE was described previously [18]. Briefly, $10 \mathrm{U}$ of $\mathrm{XbaI}$ were used for the restriction digestion. Isolates were defined as the subgenotype for those with $\leq 3$ fragment differences and as the genotype for those with $>3$ fragment differences. Plasmid size and number were analyzed using the Kado-Liu method [19], and Salmonella Choleraesuis OU7085 (6.6- and 50-kb plasmids) and S. Choleraesuis OU7526 (50- and 90-kb plasmids) as a control. Furthermore, the plasmid replicon groups FIA, FIB, FIC, HI1, HI2, I1-Igamma, L/M, N, P, W, T, A/C, K, B/O, X, Y, F, and FIIA were identified for each isolate by PCR amplification [20]. Full-length $b l a_{\mathrm{CTX}-\mathrm{M}-3-\text { like }}$ was sequenced and aligned to the NCBI database. MLST was performed using previously described methods [21]. After PCR amplification and sequencing, MLST ST types were determined at http://mlst.ucc.ie/.

\subsection{Plasmid Conjugation}

Sodium azide-susceptible clinical recurrent $E$. coli isolates and sodium azide-resistant $E$. coli strain J53 were used as donors and recipient, respectively, for conjugation experiments. After the co-culture of recipient and donor strains on filter paper on MHA agar overnight, the mixture was plated onto MacConkey agar with the appropriate antibiotic and sodium azide. Plasmid profile of the transconjugants was analyzed using the Kado-Liu method. The replicons of the conjugation plasmid were examined as above [20].

\section{Results}

These ESBL-producing E. coli isolates were predominantly collected from IUC (43\%) and urine (26\%), followed by blood and sputum, wounds (Table 2).

\subsection{Antimicrobial Resistance}

In general, all isolates were multidrug resistant to AMP, CRO and CTX and PIP with the least antimicrobial resistance for the urine group and the highest antimicrobial resistance for the IUC group (Table 2). The average resistance rate was $54 \%$ to TZP (range: $42.3 \%$ for the urine group to $66.7 \%$ for the wound group); $76 \%$ to CAZ (range: $65.4 \%$ in the urine group to $91.7 \%$ in the blood group); $60.9 \%$ to FEP (range: $57.7 \%$ for the urine group to $70 \%$ for the sputum group); less than $10 \%$ to carbapenems, including ETP, IPM and MEM, with the value observed highest in the urine group; near $90 \%$ to fluoroquinolones; over $95 \%$ to nalidixic acid; and near $90 \%$ to CIP, LVX, and MXF, particularly differing between the urine and IUC groups, with the lowest found in the blood and wound groups.

\subsection{ESBL-Related bla Genes}

The bla genes differed in prevalence among the isolation source (Table 3). The most prevalent bla gene was

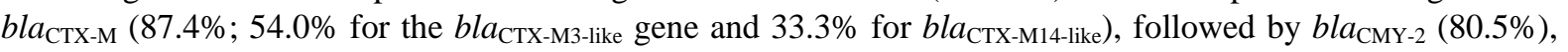


Table 1. Primer sequences and PCR product size of genes for antimicrobial resistance and virulence factors.

\begin{tabular}{|c|c|c|c|c|}
\hline PCR & Gene & Primer & Nucleotide sequence $\left(5^{\prime} \rightarrow 3^{\prime}\right)$ & Product size (bp) \\
\hline \multirow{12}{*}{$\begin{array}{l}\text { Multiplex } \\
\text { I }\end{array}$} & \multicolumn{4}{|c|}{ Class A $\beta$-lactamase } \\
\hline & \multirow{2}{*}{$b l a_{\mathrm{CTX}-\mathrm{M}-3}$} & $\mathrm{~F}$ & AATCACTGCGCCAGTTCACGCT & \multirow{2}{*}{479} \\
\hline & & $\mathrm{R}$ & GAACGTTTCGTCTCCCAGCTGT & \\
\hline & \multirow{2}{*}{$b l a_{\text {CTX-M-14 }}$} & $\mathrm{F}$ & TACCGCAGATAATACGCAGGTG & \multirow{2}{*}{355} \\
\hline & & $\mathrm{R}$ & CAGCGTAGGTTCAGTGCGATCC & \\
\hline & \multirow{2}{*}{$b l a_{\mathrm{SHV}}$} & F & AACGGAACTGAATGAGGCGCT & \multirow{2}{*}{141} \\
\hline & & $\mathrm{R}$ & TCCACCATCCACTGCAGCAGCT & \\
\hline & \multirow{2}{*}{$b l a_{\text {TEM }}$} & F & GAAGATCAGTTGGGTGCACGAGT & \multirow{2}{*}{520} \\
\hline & & $\mathrm{R}$ & CAACTTTATCCGCCTCCATCCAGT & \\
\hline & \multicolumn{4}{|c|}{ Class C $\beta$-lactamase } \\
\hline & \multirow{2}{*}{$b l a_{\mathrm{DHA}}$} & $\mathrm{F}$ & AACTTTCACAGGTGTGCTGGGT & \multirow{2}{*}{405} \\
\hline & & $\mathrm{R}$ & CCGTACGCATACTGGCTTTGC & \\
\hline \multirow{2}{*}{ Simplex } & \multirow{2}{*}{$b^{b l a} a_{\mathrm{CMY}-2}$} & $\mathrm{~F}$ & CTGACAGCСТСТTTCTCСАСА & \multirow{2}{*}{1100} \\
\hline & & $\mathrm{R}$ & CTACGTAGCTGCCAAATCCAC & \\
\hline \multirow{14}{*}{$\begin{array}{l}\text { Multiplex } \\
\text { II }\end{array}$} & \multirow{2}{*}{ hlyA } & $\mathrm{F}$ & AACAACGATAAGCACTGTTCTGG & \multirow{2}{*}{1177} \\
\hline & & $\mathrm{R}$ & CCATATAAGCGGTCATTCCCG & \\
\hline & \multirow{2}{*}{ usp } & $\mathrm{F}$ & GGAAAATGGTCGCTCAGTGG & \multirow{2}{*}{992} \\
\hline & & $\mathrm{R}$ & CTGTAGTGAATCTCATCGTGTAGTC & \\
\hline & \multirow{2}{*}{ sat } & $\mathrm{F}$ & TCAGAAGCTCAGCGAATCATTG & \multirow{2}{*}{931} \\
\hline & & $\mathrm{R}$ & CATTATCACCAGTAAAACGCACC & \\
\hline & \multirow{2}{*}{ fyuA } & $\mathrm{F}$ & GGCTTTATCCTCTGGCCTT & \multirow{2}{*}{878} \\
\hline & & $\mathrm{R}$ & GAAAACCCAGTCATCGGTGG & \\
\hline & \multirow{2}{*}{ iron } & $\mathrm{F}$ & CTCTGGTGGTGGAAGCC & \multirow{2}{*}{815} \\
\hline & & $\mathrm{R}$ & TGTCGGTACAGGCGGTTC & \\
\hline & int & $\mathrm{F}$ & CACTCCGGTACTCCAGTCA & 600 \\
\hline & & $\mathrm{R}$ & CСTCCAACCAGATGTTCTTCG & 000 \\
\hline & . & $\mathrm{F}$ & CCGGAGAAGCCTGAAATATATTCA & 504 \\
\hline & 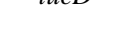 & $\mathrm{R}$ & CCGGATTGTCATATGCAGACC & דיד \\
\hline & fim $H$ & $\mathrm{~F}$ & GTTTATAATTCGAGAACGGATAAGCC & 491 \\
\hline & & $\mathrm{R}$ & GTGCATAATTTGCCGTTAATCCC & \\
\hline & nf 1 & $\mathrm{~F}$ & TTCTTCTGTACTTCCССCAG & 108 \\
\hline & (IIII & $\mathrm{R}$ & TGAGCGGCATCTACTATGAAGT & 400 \\
\hline Multiplex & $\operatorname{traT}$ & $\mathrm{F}$ & CATAACCACGGTTCAGCCATC & 328 \\
\hline III & & $\mathrm{R}$ & TTGCACTGGTCAGTTCCAC & 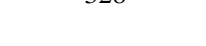 \\
\hline & knsMTUL & $\mathrm{F}$ & CATCAGACGATAAGCATGAGCA & 260 \\
\hline & קP & $\mathrm{R}$ & TGCGCATTTGCTGATACTGT & 200 \\
\hline & & $\mathrm{F}$ & GGGCCCССAAGTAACTC & 189 \\
\hline & pups in & $\mathrm{R}$ & GGATGAGCGGGCCTTTG & 100 \\
\hline
\end{tabular}




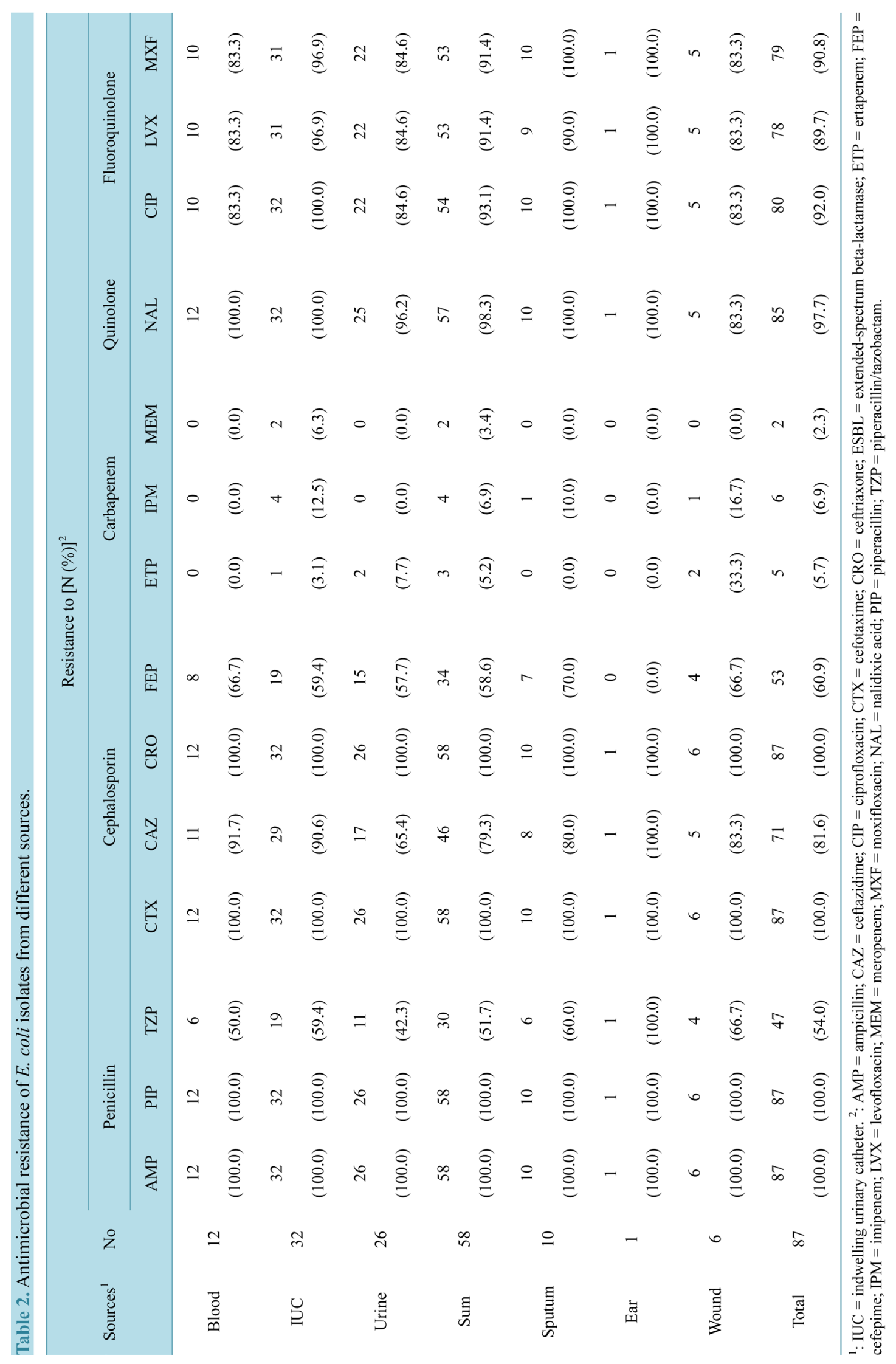


Table 3. Prevalence of bla genes in ESBL-producing E. coli isolates from different sources.

\begin{tabular}{|c|c|c|c|c|c|c|c|c|c|c|}
\hline \multirow{2}{*}{ Source } & \multirow{2}{*}{ No } & \multicolumn{2}{|c|}{ ESBL phenotype [N (\%)] } & \multicolumn{7}{|c|}{ bla genes $[\mathrm{N}(\%)]$} \\
\hline & & СTX & CAZ & TEM & CMY-2 & SHV & DHA & CTX-M & CTX-M-3 like & CTX-M-14-like \\
\hline \multirow{2}{*}{ Blood } & \multirow{2}{*}{12} & 10 & 8 & 4 & 9 & 6 & 0 & 10 & 6 & 4 \\
\hline & & (83.3) & $(66.7)$ & (33.3) & $(75.0)$ & $(50.0)$ & $(0.0)$ & (83.3) & $(50.0)$ & (33.3) \\
\hline \multirow{2}{*}{ IUC } & \multirow{2}{*}{32} & 27 & 25 & 11 & 28 & 20 & 0 & 27 & 18 & 9 \\
\hline & & $(84.4)$ & $(78.1)$ & $(34.4)$ & $(87.5)$ & $(62.5)$ & $(0.0)$ & $(84.4)$ & $(56.3)$ & $(28.1)$ \\
\hline \multirow{2}{*}{ Urine } & \multirow{2}{*}{26} & 23 & 18 & 14 & 20 & 13 & 2 & 24 & 13 & 11 \\
\hline & & (88.5) & $(69.2)$ & $(53.8)$ & (76.9) & $(50.0)$ & $(7.7)$ & $(92.3)$ & $(50.0)$ & $(42.3)$ \\
\hline \multirow{2}{*}{ Sum } & \multirow{2}{*}{58} & 50 & 43 & 25 & 48 & 33 & 2 & 51 & 31 & 20 \\
\hline & & $(86.2)$ & $(74.1)$ & $(43.1)$ & (82.8) & (56.9) & (3.4) & (87.9) & (53.4) & (34.5) \\
\hline \multirow{2}{*}{ Sputum } & \multirow{2}{*}{10} & 8 & 6 & 2 & 7 & 5 & 0 & 9 & 6 & 3 \\
\hline & & $(80.0)$ & (60.0) & $(20.0)$ & (70.0) & (50.0 & $(0.0)$ & (90.0) & $(60.0)$ & (30.0) \\
\hline \multirow{2}{*}{ Ear } & \multirow{2}{*}{1} & 0 & 0 & 0 & 1 & 1 & 0 & 0 & 0 & 0 \\
\hline & & $(0.0)$ & $(0.0)$ & $(0.0)$ & (100.0) & (100.0) & $(0.0)$ & $(0.0)$ & $(0.0)$ & $(0.0)$ \\
\hline \multirow{2}{*}{ Wound } & \multirow{2}{*}{6} & 4 & 6 & 1 & 5 & 4 & 0 & 6 & 4 & 2 \\
\hline & & (66.7) & (100.0) & (16.7) & (83.3) & $(66.7)$ & $(0.0)$ & (100.0) & (66.7) & (33.3) \\
\hline \multirow{2}{*}{ Total } & \multirow{2}{*}{87} & 72 & 63 & 32 & 70 & 49 & 2 & 76 & 47 & 29 \\
\hline & & (82.8) & $(72.4)$ & (36.8) & (80.5) & (56.3) & (2.3) & (87.4) & (54.0) & (33.3) \\
\hline
\end{tabular}

1: IUC = indwelling urinary catheter.

$b l a_{\mathrm{SHV}}(56.3 \%), b l a_{\mathrm{TEM}}(36.8 \%)$ and $b l a_{\mathrm{DHA}}(2.3 \%)$. Overall, $67.4 \%$ of the isolates carried at least 3 bla genes. For example, $b l a_{\mathrm{CTX}-\mathrm{M}-3-\text {-like }}, b l a_{\mathrm{CMY}}$, and $b l a_{\mathrm{SHV}}$ were observed in $31.6 \%$ of the isolates. The prevalence of $b l a_{\mathrm{TEM}}$ ranged from $16.7 \%$ for the wound group to $53.8 \%$ in the urine group; the prevalence of $b l a_{\mathrm{CMY}-2}$ ranged from $70.0 \%$ for the sputum group to $85.4 \%$ for the IUC group. The prevalence of $b l a_{\mathrm{SHV}}$ ranged from $50 \%$ for the blood and sputum group to $66.7 \%$ in the wound group. The prevalence of $b l a_{\mathrm{CTX-M} 3 \text {-like }}$ ranged from $52 \%$ for the urine group and blood group to $66.7 \%$ for the wound group. The prevalence of $b l a_{\text {СтX-M14-like }}$ ranged from $28.1 \%$ in the IUC group to $42.3 \%$ in the urine group. The $b l a_{\text {СтX-м3-like }}$ and $b l a_{\text {СTX-M14-like }}$ that were present were mutually exclusive. The gene $b l a_{\mathrm{DHA}}$ was identified in only two urine isolates.

\subsection{Differences in Virulence Genes in Pathogenicity Islands (PAI $\left.{ }_{536}\right)$ of UPEC}

In contrast to the more than $80 \%$ of isolates that carried type I fimbrae fimH, the prevalence of the pathogenicity island-associated fimbrial gene papGII ranged from $22 \%$ for the wound group to $67 \%$ for the blood group (Table 3 ). Over $50 \%$ of the urine and bacteremia isolates carried the capsular gene kpsMTII. The toxin genes cnf 1 and hlyA were more highly observed in bacteremia isolates. Among the three siderophore types, aerobactin genes (iutA and $i u c D$ ) and the yersiniabactin gene (fyuA) were present in over $80 \%$ of the isolates, whereas the salmochelin gene $i r o N$ was nearly absent. The fyuA gene was present in over $90 \%$ of the wound and urine groups and in only $56 \%$ of the sputum group. The uropathogenic protein gene usp was found in more bacteremia and UTI groups (75\% and 68\%) than sputum group (55\%). The gene sat was most often found in the IUC group (Table 4).

\subsection{Genetic Variations in 18 E. coli Isolates from Recurrent Infections and Different Locations in Same Patient}

These isolates were obtained mostly from urine and IUC and belonged to uropathogenic ST131 of pulsotypes I (IA and IB) and II (IIA and IIB), except ST95 of pulsotype III for patient 5 (Table 5). Furthermore, all pulsotype 


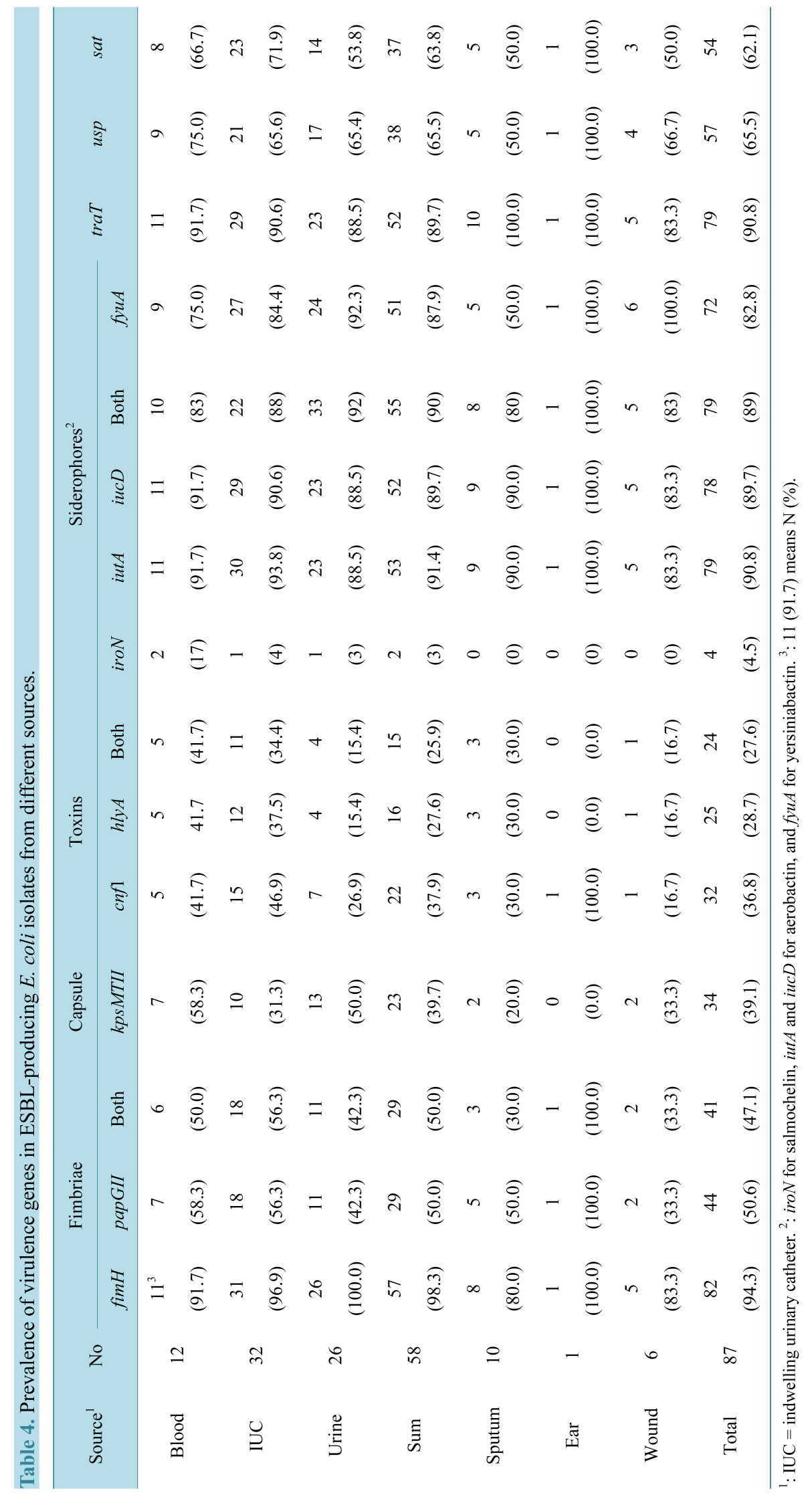




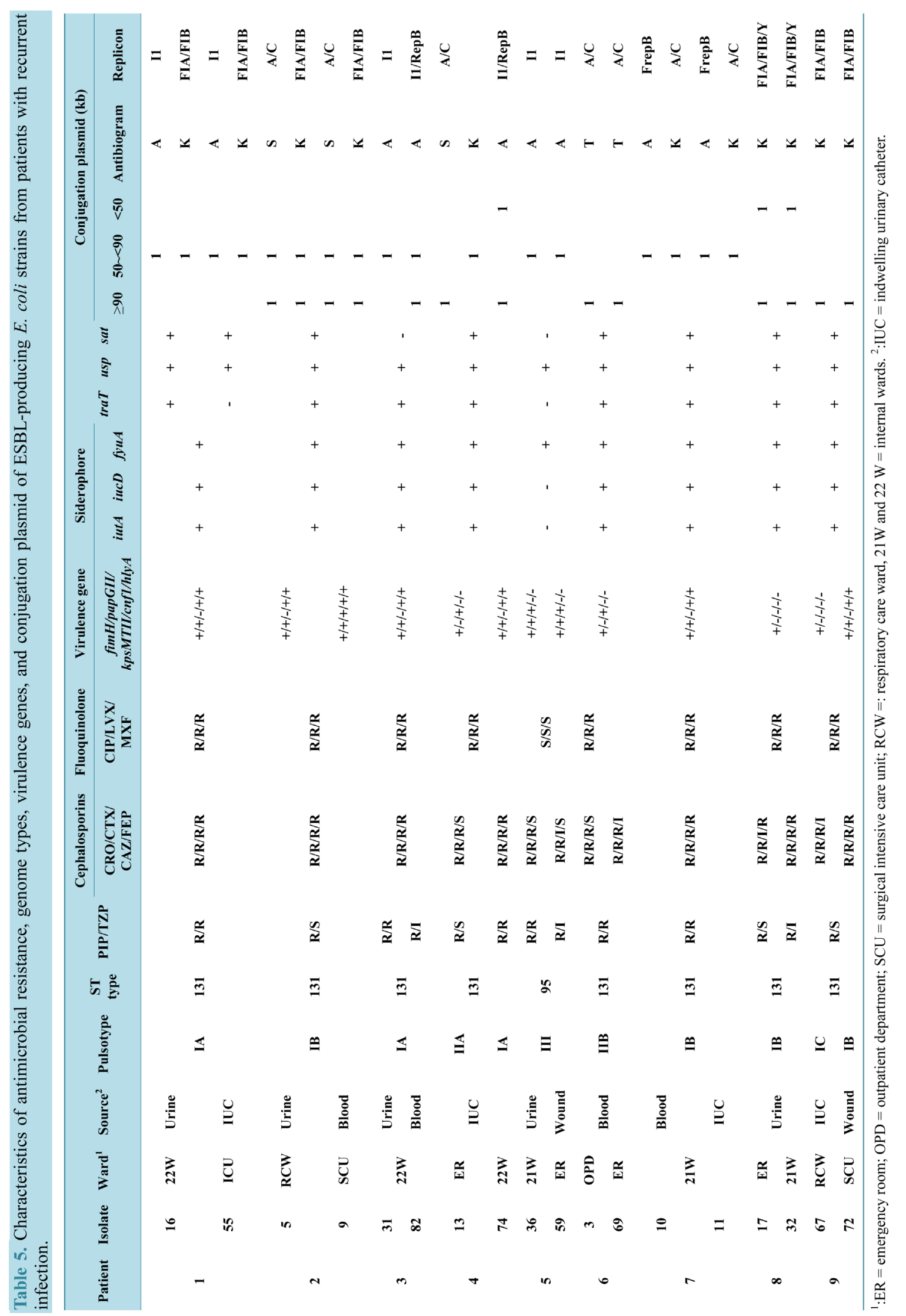


IA isolates were collected from ward 22W. Among the virulence genes, these isolates carried the siderophore genes iut $A B$ and fyuA and usp (Table 5). Except for isolate 9, all isolates missed at least one virulence gene from fimH, papGII, kpsMTII, cnf1, and hlyA. The ST 95 isolates from patient 5 carried fewer siderophore genes, lacked the genes traT and sat and were sensitive to fluoroquinolone compared to the ST131 isolates, which were all fluoroquinolone-resistant and resistant to cefotaxime (CTX), ceftazidime (CAZ), and ceftriaxone (CRO), of the third-generation cephalosporins. Furthermore, few isolates were resistant to fourth-generation cefepime (FEF). Among the four bla genes examined by PCR and sequencing, bla $a_{\mathrm{CTM}-\mathrm{M} 15}$ was the most prevalent bla gene and was potentially located on the IncF plasmid (Figure 1). Furthermore, the AmpC gene $b l a_{\mathrm{CMY}-2}$ was detected with high prevalence (15/18).

Plasmid profile differed in size and number, ranging from $6.6 \mathrm{~kb}$ to larger than $90 \mathrm{~kb}$ (Figure 1). Four plasmids were common, with sizes less than 50-kb (1), 50 - $90 \mathrm{~kb}$ (2) and larger than $90 \mathrm{~kb}$ (1). Among the 18 plasmid replicon types tested, only five replicon types A/C, I1, FIA, FIB and Y were identified, and the plasmid with these replicons could be conjugated (Table 5). Replicon types combined with PFGE, ST, and plasmid analysis demonstrated identical isolates in patients 2, 5, 6, 7, and 8 and different isolates in patients 1, 3, 4, and 9.

\section{Discussion}

E. coli is the major pathogen for clonal community-acquired and nosocomial UTIs [1] [22]-[24]. In addition, CAUTIs are a major nosocomial infection in hospitals and nursing homes [8]. In this study, in a nursing home in this hospital, CAUTIs (IUCs) were more common than UTIs (Table 2). We confirmed that fluoroquinoloneresistant ESBL-producing E. coli infections caused more than $80 \%$ of the UTIs and bacteremia observed in older patients [25]. The pathogenicity island (PAI) $\mathrm{I}_{536}-\mathrm{IV}_{536}$ carries genes for UPEC to cause bacteremia [6]. Indeed, virulence genes of PAI-I $\mathrm{I}_{536}-\mathrm{IV}_{536}$ were found to be more common in the isolates from urine, IUC and blood than in those from sputum and wounds, but these genes differed among the UTI, IUC and blood groups. For example, papGII and kpsMTII were more common in the blood group than in IUCs and UTIs, and the fimbriae genes fimH and papGII, toxin genes $c n f 1, h l y A$, and sat were more common in the IUC group than in the UTI group (Table 3). These results suggest the different origins of blood, IUC and urine groups. Our study also demonstrated that the ESBL-producing isolates and recurrent UPEC ST131 mostly consisted of yersiniabactin and aerobactin genes, and lacked the salmochelin gene (Tables 3-5), which confirmed that yersiniabactin and aerobactin are more prevalent in relapsed UPEC isolates [26]. Additionally, yersiniabactin are more common in

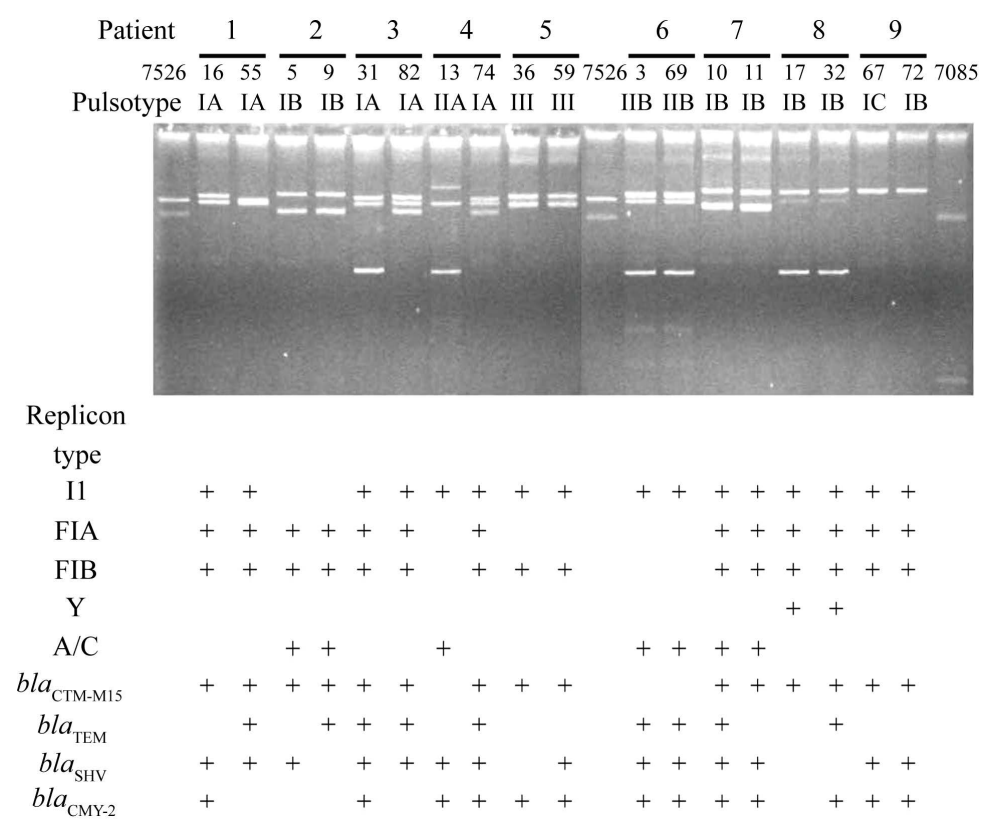

Figure 1. Plasmid profile and replicon type and bla genes in recurrent E. coli isolates. A: Plasmid analysis. Size standards are $90-\mathrm{kb}$ and $50-\mathrm{kb}$ plasmids of OU7526 and the 50-kb and 6.6-kb plasmids of OU7085. 
ST131 than non-ST131 strains [27], implying different strains between sputum isolates and the blood and UTI isolates (Table 3).

E. coli ST131 and ST95 isolates have been the major UPEC isolates causing UTI in Canada and the USA [28] [29]. Our study demonstrated clonal dissemination of ST131 with $b l a_{\text {CTX-M-15, }}$, such as pulsotype IA isolates in ward 22W and most pulsotype IB isolates in 21W and SCU (Table 5, Figure 1), which confirmed that the clonal dissemination of UPEC infection is often responsible for recurrent infection in patients due to ineffective treatment [26] as well as for recurrent bloodstream infection in elderly patients [30]. In addition, these isolates frequently carry the CTX-M ESBL enzyme [31].

Fluoroquinolone-resistant E. coli ST131 carried a plasmid that was capable of conjugation in which replicon types IncF were the most prevalent. Inc I1-I $\gamma, \mathrm{K}, \mathrm{HI} 2$ and B/O [32] and E. coli ST131 were isolated in UK river sediment and carried $b l a_{\mathrm{CTX}-\mathrm{M}-15}$, which is associated with the replicon IncF plasmid [33]. Furthermore, $b l a_{\text {CTX-M-15 }}$ was identified in 100-335-kb Inc FII, IncHI2, IncY plasmids and other non-typeable plasmids, with a size ranging from 70 - $330 \mathrm{~kb}$ [34]. Carbapenem-resistant $E$. coli ST131with bla $\mathrm{KPC}_{\text {on }}$ on conjugable plasmid has been identified [35]. However, we only observed reduced susceptibility to carbapenem in this study. In the present study, fluoroquinolone-resistant ESBL-producing $E$. coli ST131 with $b l a_{\text {CTX-M-15 }}$ evolved differently via an increase in genomic variation (Figure 1) and the transfer of plasmids that differed in size, number and replicon types, suggesting a genome plasticity in both the plasmid and chromosome that have resulted in the greater pathogenicity of ST131 and its rapid dissemination worldwide.

\section{Conclusion}

In conclusion, fluoroquinolone-resistant ESBL-producing E. coli differed in the virulence genes of PAI-I $\mathrm{I}_{536}-\mathrm{IV}_{536}$ of UPEC. Uropathogenic E. coli ST131 was dominant in this hospital, and it evolves genetically via plasmid transfer and chromosome variations.

\section{Acknowledgements}

The authors would like to acknowledge funding from Chiayi Branch, Taichung Veterans Hospital (RVHCY990002 and RVHCY100005) and the National Science Council (NSC98-2321-B-415-003), Executive Yuan, Taiwan.

\section{References}

[1] Dias, R.C., Marangoni, D.V., Smith, S.P., Elizabeth, M.A., Pellegrino, F.L.P.C., Riley, L.W. and Moreira, B.M. (2009) Clonal Composition of Escherichia coli Causing Community-Acquired Urinary Tract Infections in the State of Rio de Janeiro, Brazil. Microbial Drug Resistance, 15, 303-308. http://dx.doi.org/10.1089/mdr.2009.0067

[2] Smith S.N., Hagan E.C., Lane M.C. and Mobley H.L. (2010) Dissemination and Systemic Colonization of Uropathogenic Escherichia coli in a Murine Model of Bacteremia. mBio, 1, e00262-10. http://dx.doi.org/10.1128/mbio.00262-10

[3] Stamm, W.E. and Hooton, T.M. (1993) Management of Urinary Tract Infections in Adults. The New England Journal of Medicine, 329, 1328-1334. http://dx.doi.org/10.1056/NEJM199310283291808

[4] Ananias, M. and Yano, T. (2008) Serogroups and Virulence Genotypes of Escherichia coli Isolated from Patients with Sepsis. Brazilian Journal of Medical and Biological Research, 41, 877-883. http://dx.doi.org/10.1590/S0100-879X2008001000008

[5] Jadhav, S., Hussain, A., Devi, S., Kumar, A., Parveen, S., Gandham, N., Wieler, L.H., Ewers, C. and Ahmed, N. (2011) Virulence Characteristics and Genetic Affinities of Multiple Drug Resistant Uropathogenic Escherichia coli from a Semi Urban Locality in India. PLoS One, 6, e18063. http://dx.doi.org/10.1371/journal.pone.0018063

[6] Lloyd A.L., Rasko D.A., and Mobley H.L. (2007) Defining Genomic Islands and Uropathogen-Specific Genes in Uropathogenic Escherichia coli. Journal of Bacteriology, 189, 3532-3546. http://dx.doi.org/10.1128/JB.01744-06

[7] Jacobsen, S.M., Stickler, D.J., Mobley, H.L. and Shirtliff, M.E. (2008) Complicated Catheter-Associated Urinary Tract Infections Due to Escherichia coli and Proteus mirabilis. Clinical Microbiology Review, 21, 26-59. http://dx.doi.org/10.1128/CMR.00019-07

[8] Stamm, W.E. (1991) Catheter-Associated Urinary Tract Infections: Epidemiology, Pathogenesis, and Prevention. American Journal of Medicine, 91, 65S-71S. http://dx.doi.org/10.1016/0002-9343(91)90345-X

[9] Warren, J.W. (1997) Catheter-Associated Urinary Tract Infections. Infectious Disease Clinics of North America, 11, 609-622. http://dx.doi.org/10.1016/S0891-5520(05)70376-7 
[10] Doi, Y., Shibata, N., Shibayama, K., Kamachi, K., Kurokawa, H., Yokoyama, K., Yagi, T. and Arakawa, Y. (2002) Characterization of a Novel Plasmid-Mediated Cephalosporinase (CMY-9) and Its Genetic Environment in an Escherichia coli Clinical Isolate. Antimicrobial Agents and Chemotherapy, 46, 2427-2434. http://dx.doi.org/10.1128/AAC.46.8.2427-2434.2002

[11] Hsieh, C.J., Shen, Y.H. and Hwang, K.P. (2010) Clinical Implications, Risk Factors and Mortality Following Community-Onset Bacteremia Caused by Extended-Spectrum $\beta$-Lactamase (ESBL) and Non-ESBL Producing Escherichia coli. Journal of Microbiology, Immunology and Infection, 43, 240-248. http://dx.doi.org/10.1016/S1684-1182(10)60038-2

[12] Wu, U.I., Yang, C.S., Chen, W.C., Chen, Y.C. and Chang, S.C. (2010) Risk Factors for Bloodstream Infections Due to Extended-Spectrum Beta-Lactamase-Producing Escherichia coli. Journal of Microbiology, Immunology and Infection, 43, 310-316. http://dx.doi.org/10.1016/S1684-1182(10)60048-5

[13] Nicolas-Chanoine, M.H., Bertrand, X. and Madec, J.Y. (2014) Escherichia coli ST131, an Intriguing Clonal Group. Clinical Microbiology Review, 27, 543-574. http://dx.doi.org/10.1128/CMR.00125-13

[14] Kao, C.Y., Udval, U., Huang, Y.T., Wu, H.M., Huang, A.H., Bolormaa, E., Yan, J.J., Urangoo, Z., Batbaatar, G., Khosbayar, T. and Wu, J.J. (2015) Molecular Characterization of Extended-Spectrum $\beta$-Lactamase-Producing Escherichia coli and Klebsiella spp. Isolates in Mongolia. Journal of Microbiology, Immunology and Infection, pii: S1684-1182(15)00763-X. http://dx.doi.org/10.1016/j.jmii.2015.05.009

[15] Papagiannitsis, C.C., Študentová, V., Jakubů, V., Španělová, P., Urbášková, P., Žemličková, H. and Hrabák, J. (2015) High Prevalence of ST131 among CTX-M-Producing Escherichia coli from Community-Acquired Infections, in the Czech Republic. Microbial Drug Resistance, 21, 74-84. http://dx.doi.org/10.1089/mdr.2014.0070

[16] Rafaï, C., Frank, T., Manirakiza, A., Gaudeuille, A., Mbecko, J.R., Nghario, L., Serdouma, E., Tekpa, B., Garin, B. and Breurec, S. (2015) Dissemination of IncF-Type Plasmids in Multiresistant CTX-M-15-Producing Enterobacteriaceae Isolates from Surgical-Site Infections in Bangui, Central African Republic. BMC Microbiology, 15, 15. http://dx.doi.org/10.1186/s12866-015-0348-1

[17] CLSI (2010) Clinical and Laboratory Standards Institute. Performance Standards for Antimicrobial Susceptibility Tests; Approved Standard, 12th Edition, M100-S20-U. Wayne, Pennsylvania.

[18] Ribot, E.M., Fair, M.A., Gautom, R., Gautom, R., Cameron, D.N., Hunter, S.B. and Barrett, T.J. (2006) Standardization of Pulsed-Field Gel Electrophoresis Protocols for the Subtyping of Escherichia coli O157:H7, Salmonella, and Shigella for PulseNet. Foodborne Pathogens and Disease, 3, 59-67. http://dx.doi.org/10.1089/fpd.2006.3.59

[19] Kado, C.I. and Liu, S.T. (1981) Rapid Procedure for Detection and Isolation of Large and Small Plasmids. Journal of Bacteriology, 145, 365-373.

[20] Carattoli, A., Bertini, A., Villa, L., Falbo, V., Hopkins, K.L. and Threlfall, E.J. (2006) Identification of Plasmids by PCR-Based Replicon Typing. Journal of Microbiological Methods, 63, 219-228. http://dx.doi.org/10.1016/j.mimet.2005.03.018

[21] Tartof, S.Y., Solberg, O.D., Manges, A.R. and Riley, L.W. (2005) Analysis of a Uropathogenic Escherichia coli Clonal Group by Multilocus Sequence Typing. Journal of Clinical Microbiology, 43, 5860-5864. http://dx.doi.org/10.1128/JCM.43.12.5860-5864.2005

[22] Bouza, E., San Juan, R., Muñoz, P., Voss, A. and Kluytmans, J., Co-Operative Group of the European Study Group on Nosocomial Infections (2001) A European Perspective on Nosocomial Urinary Tract Infections II. Report on Incidence, Clinical Characteristics and Outcome (ESGNI-004 Study). European Study Group on Nosocomial Infection. Clinical Microbiology and Infection, 7, 532-542. http://dx.doi.org/10.1046/j.1198-743x.2001.00324.x

[23] Haley, R.W., Culver, D.H., White, J.W., Morgan, W.M., Emori, T.G. and Munn, V.P. (1985) The Efficacy of Infection Surveillance and Control Programs in Preventing Nosocomial Infections in US Hospitals. American Journal of Epidemiology, 121, 182-205.

[24] Hooton, T.M. and Stamm, W.E. (1997) Diagnosis and Treatment of Uncomplicated Urinary Tract Infection. Catheter-Associated Urinary Tract Infections. Infectious Disease Clinics of North America, 11, 551-581. http://dx.doi.org/10.1016/S0891-5520(05)70373-1

[25] Díaz, M.A., Hernández-Bello, J.R., Rodríguez-Baño, J., Martínez-Martínez, L., Calvo, J., Blanco, J., Pascual, A. and Spanish Group for Nosocomial Infections (GEIH) (2010) Diversity of Escherichia coli Strains Producing ExtendedSpectrum Beta-Lactamases in Spain: Second Nationwide Study. Journal of Clinical Microbiology, 48, 2840-2845. http://dx.doi.org/10.1128/JCM.02147-09

[26] Ejrnaes, K., Sandvang, D., Lundgren, B., Ferry, S., Holm, S., Monsen, T., Lundholm, R. and Frimodt-Moller, N. (2006) Pulsed-Field Gel Electrophoresis Typing of Escherichia coli Strains from Samples Collected before and after Pivmecillinam or Placebo Treatment of Uncomplicated Community-Acquired Urinary Tract Infection in Women. Journal of Clinical Microbiology, 44, 1776-1781. http://dx.doi.org/10.1128/JCM.44.5.1776-1781.2006 
[27] Olesen, B., Hansen, D.S., Nilsson, F., Frimodt-Møller, J., Leihof, R.F., Struve, C., Scheutz, F., Johnston, B., Krogfelt, K.A. and Johnson, J.R. (2013) Prevalence and Characteristics of the Epidemic Multiresistant Escherichia coli ST131 clonal Group among Extended-Spectrum Beta-Lactamase-Producing E. coli Isolates in Copenhagen, Denmark. Journal of Clinical Microbiology, 51, 1779-1785. http://dx.doi.org/10.1128/JCM.00346-13

[28] Manges, A.R., Tabor, H., Tellis, P., Vincent, C. and Tellier, P.P. (2008) Endemic and Epidemic Lineages of Escherichia coli that Cause Urinary Tract Infections. Emerging Infectious Diseases, 14, 1575-1583. http://dx.doi.org/10.3201/eid1410.080102

[29] Floyd, R.V., Upton, M., Hultgren, S.J., Wray, S., Burdyga, T.V. and Winstanley, C. (2012) Escherichia coli-Mediated Impairment of Ureteric Contractility Is Uropathogenic E. coli Specific. Journal of Infectious Diseases, 206, 1589-1596. http://dx.doi.org/10.1093/infdis/jis554

[30] Al-Hasan, M.N., Eckel-Passow, J.E. and Baddour, L.M. (2010) Recurrent Gram-Negative Bloodstream Infection: A 10-Year Population-Based Cohort Study. Journal of Infection, 61, 28-33. http://dx.doi.org/10.1016/j.jinf.2010.03.028

[31] Brisse, S., Diancourt, L., Laouénan, C., Vigan, M., Caro, V., Arlet, G., Drieux, L., Leflon-Guibout, V., Mentré, F., Jarlier, V., Nicolas-Chanoine, M.H. and Coli $\beta$ Study Group (2012) Phylogenetic Distribution of CTX-M- and Non-Extended-Spectrum- $\beta$-Lactamase-Producing Escherichia coli Isolates: Group B2 Isolates, Except Clone ST131, Rarely Produce CTX-M Enzymes. Journal of Clinical Microbiology, 50, 2974-2981. http://dx.doi.org/10.1128/JCM.00919-12

[32] Varela, A.R., Macedo, G.N., Nunes, O.C. and Manaia, C.M. (2015) Genetic Characterization of Fluoroquinolone Resistant Escherichia coli from Urban Streams and Municipal and Hospital Effluents. FEMS Microbiology Ecology, 91, fiv015. http://dx.doi.org/10.1093/femsec/fiv015

[33] Amos, G.C., Hawkey, P.M., Gaze, W.H. and Wellington, E.M. (2014) Waste Water Effluent Contributes to the Dissemination of CTX-M-15 in the Natural Environment. Journal of Antimicrobial Chemotherapy, 69, 1785-1791. http://dx.doi.org/10.1093/jac/dku079

[34] Ribeiro, T.G., Novais, Â., Peixe, L. and Machado, E. (2016) Atypical Epidemiology of CTX-M-15 among Enterobacteriaceae from a High Diversity of Non-Clinical Niches in Angola. Journal of Antimicrobial Chemotherapy, 71, 11691173. http://dx.doi.org/10.1093/jac/dkv489

[35] Piazza, A., Caltagirone, M., Bitar, I., Nucleo, E., Spalla, M., Fogato, E., D’Angelo, R., Pagani, L. and Migliavacca, R. (2016) Emergence of Escherichia coli Sequence Type 131 (ST131) and ST3948 with KPC-2, KPC-3 and KPC-8 Carbapenemases from a Long-Term Care and Rehabilitation Facility (LTCRF) in Northern Italy. Advances in Experimental Medicine and Biology, 901, 77-89.

\section{Submit or recommend next manuscript to SCIRP and we will provide best service for you:}

Accepting pre-submission inquiries through Email, Facebook, LinkedIn, Twitter, etc.

A wide selection of journals (inclusive of 9 subjects, more than 200 journals)

Providing 24-hour high-quality service

User-friendly online submission system

Fair and swift peer-review system

Efficient typesetting and proofreading procedure

Display of the result of downloads and visits, as well as the number of cited articles

Maximum dissemination of your research work

Submit your manuscript at: http://papersubmission.scirp.org/ 